\title{
Tuntutan Akuntabilitas Masyarakat terhadap Pemerintah atas Pajak dan Retribusi
}

\author{
Surifah
}

The several criticisms toward the accountability of the government in term of tax policy either in its legislation, tax act or the implementation of tax legislation. There are many problems in this context, for instance unqualified human resources, the benefit of tax that not transparancy yet. Accountability that needed by society should be conducted by the government and constituted the rights of society to accept. The efforts that have been done by government to increase the accountability is stiil needs workhard and involving many parts of society so that be more efficiency and effectivity.

Kata Kunci: akuntabilitas, hukum, pajak, pemerintah

Oada era reformasi yang bertekanan pada demokrasi, tuntutan masyarakat terhadap akuntabilitas pemerintah yang khususnya dalam bidang pajak dan retribusi semakin tinggi. Sebelum era reformasi, istilah accountability (akuntabilitas) kurang familier dibandingkan dengan istilah responsibility (pertanggungjawaban). Responsibility lebih bersifatinternal sebagai pertanggungjawaban bawahan kepada atasan yang telah memberikan tugas dan wewenang, yang biasanya terbatas pada bidang keuangan saja, sedangkan accountability lebih bersifat eksternal ' sebagai tuntutan pertanggungjawaban darimasyarakatterhadap apa sajayang telah dilakukan oleh para pejabat atau aparat. Tulisan ini akan membahas mengenai ruang lingkup akuntabilitas dan kritik terhadap akuntabilitas pemerintah, dampak kurang-nya/meningkatnya akuntabilitas, Upaya untuk meningkatkan akuntabilitas, dan kesimpulan.

\section{Akuntabilitas dan Kritik terhadap Akuntabilitas Pemerintah}

Ruang lingkup akuntabilitas tidak hanya pada bidang keuangan saja, tetapi meliputi (Utomo, 2000):

- Kemauan dan kesiapan aparat untuk mempertanggungjawabkan kepada masyarakat atau publik mengenai penggunaan atau pemanfaatan kekuasaan dan kekhususan dari lembaga negara di mana seseorang bekerja.

- Penggunaan atau pemanfaatan sumber daya manusia (SDM) dan manajemen SDM-nya. 
- Kinerja personal dari pekerjaanpekerjaan sebagai aparat.

Dengan demikian yang dituntut oleh masyarakat tidak hanya Fiscal accountability, tetapi juga legal accountability, program accountability, process accountability, dan outcome accountability. Akuntabilitas yang dituntut oleh masyarakat ini bukan suatu norma yang baru, tetapi merupakan sesuatu yang harus dilakukan oleh pemerintah dan merupakan hak yang harus diterima oleh masyarakat.

\section{Fiscal Accountability}

Akuntabilitas yang dituntut masyarakat berkaitan dengan pajak dan retribusi di bidang keuangan adalah yang berkaitan dengan pemanfaatan hasil perolehan pajak dan retribusi. Apabila masyarakat merasa tidak memperoleh faedah atas beban pajak dan retribusi yang dibayarnya dan tidak mengerti bagaimana pemanfaatan serta alokasi hasil perolehan pajak dan retribusi, maka tuntutan akuntabilitas tersebut muncul. Meskipun pada pembayaran pajak, masyarakat tidak memperoleh imbalan yang langsung, tetapi sebagai warga negara yang telah memenuhi kewajibannya maka masyarakat berhak untuk menuntut pertanggung jawab penggunaan pajak tersebut. Apalagi penarikan retribusi yang secara langsung seharusnya dinikmati oleh pembayar atau Wajib Retribusi maka masyarakat juga menuntut adanya fasilitasfasilitas atau bentuk pelayanan untuk kemudahan-kemudahan dan kelancarankelancaran, serta tuntutan masyarakat adanya transparansi terhadap pembuatan, implementasi maupun penggunaan pajak dan retribusi.

Transparansi penggunaan perolehan pajak dan retribusi harus didukung antara lain dengan transparansi terhadap pelaksanaan anggaran negara. Dinyatakan oleh Sujanto (2001), peraturan tentang pelaksanaan anggaran negara adalah faktor utama pendorong terjadinya kebocoran dana anggaran di setiap lini birokrasi. Padahak pelaksanaan anggaran itu sendiri didominasi oleh adanya unsur ketidakpercayaan yang kemudian melahirkan gagasan untuk melahirkan pengawasan, yang diwujudkan dalam bentuk adanya tahap-tahapan dalam pelaksanaan anggaran, yang setiap tahapan dipercayakan pada person berbeda-beda. Namun kenyataannya paktik pelaksanaan anggaran tersebut kini melahirkan permasalahan besar, yaitu kebocoran dana anggaran yang dilakukan oleh berbagai pihak, bukan saja di kalangan birokrasi, tetapi juga di kalangan non birokrasi.

Sinyalemen di atas menunjukkan bahwa Akuntabilitas keuangan yang ada selama ini masih jauh dari yang diharapkan oleh masyarakat. Meskipun mekanisme akuntabilitas sudah ada yaitu dalam bentuk pertanggungjawaban melaluj DPR, melalui mekanisme ministerial, independent body, atau melalui mekanisme administrative tribunal atau PTUN (Peradilan Tata Usaha Negara).

\section{Legal Accountabiliy}

Akuntabilitas yang dituntut masyarakat berupa legal accountability adalah berkaitan dengan bagaimana undang-undang maupun peraturan pajak dan retribusi ini berprinsip pada keadilan, pemerataan, kepastian, terprediksi, objektif dan rasional. Meskipun berbagai reformasi pajak sudah dilakukan, namun masih terdapat banyak kekurangankekurangan yang ada pada sistem perpajakan kita, sehingga masih jauh dari prinsip tersebut. Permasalahan perpajakan di Indonesia antara lain adalah: 
1. Indonesia menerapkan sistem tarif pajak yang tinggi namun berbasis pajak yang sempit. Dalam pasar global yang semakin kompetitif, hal ini seharusnya tidak dipertahankan. Perlu adanya basis pajak baru sehingga bisa memberikan insentif kepada pasar bebas guna menarik uang ke Indonesia atau menjaga uang yang diperoleh di sini agar tetap berada di Indonesia. Jadi fokusnya adalah ekspansi ekonomis untuk memperluas basis pajak dan bukan pada jumlah penerimaannya.

2. Undang-undang perpajakan yang makin tidak sederhana. Salah satu contoh adalah "UU No. 16 tahun 2000 tentang perubahan Undang-undang mengenai ketentuan umum dan tata cara perpajakan, mengubah UU No. 16 tahun 1983, sebagaimana diubah dengan UU No. 9 tahun $1994^{\prime \prime}$..., ini berarti bahwa UU tahun 1983 masih tetap ada, meskipun sudah mengalami perubahan, sehingga terdapat $3 \mathrm{UU}$ mengenai KUP. Subroto (2001), menyarankan, seyogyanya UU yang sudah terlalu banyak ditambal sulam itu disederhanakan dengan dicabut dan diganti saja dengan satu UU yang disusun dengan cara mengakomodir isi dari UU terdahulu yang masih berlaku dengan penyempurnaan yang dianggap perlu, sehingga hanya ada satu UUKUP, UU-PPH atau UU-PPN.

3. Terdapat beberapa pokok perubahan UU pajak tahun 2000 yang kurang kondusif, Hidayat (2001), yaitu: a) bagi wajib pajak yang memiliki tempat usaha di beberapa tempat diwajibkan mendafatar pada KPP domisili usaha (pasal 2 ayat 3 , UU No. 16), hal ini memberatkan sebagian besar WP eceran/kecil, karena tempat usaha biasanya hanya menyewa untuk beberapa waktu, b) UU PPN yang sebelumnya menganut sistem cash basis, diubah menjadi accrual basis, dan tidak memberi toleransi pada jenis usaha tertentu untuk memilih penggunaan cash basis atau accrual basis, hal ini dapat memberatkan karena ada bebarapa jenis usaha yang akan lebih realistis bila mengakui pendapatan dan bebannya dengan menggunakan cash basis, c) Tarif 'PPnBM terhadap beberapa produk tertentu mengalami kenaikan yang berdapat pada harga jual menjadi bertambah tinggi, dan pada akhirnya akan mengurangi minat konsumen terhadap barang tersebut, hal ini juga akan sangat berpengaruh bagi pengusaha khusus yang terlibat dalam jenis-jenis barang yang berkategori mewah. d) Tidak dibuatnya masa daluwarsa yang panjang ( 10 tahun) bagi WP cukup menjadi beban, baik secara material maupun secara psikologis.

\section{Program accountability}

Akuntabilitas yang dituntut masyarakat berupa program accountability adalah berkaitan dengan bagaimana supaya pemerintah untuk terus menerus memperbaiki undang-undang dan peraturan pajak dan retribusi, sistem dan prosedur serta implementasi dan pelaksanaan pajak. Upaya-upaya pemerintah ini terus dilakukan, antara lain yaitu dengan reformasi perpajakan sejak tahun 1983, 1994 dan tahun 2000, yaitu terutama tentang UU tentang Ketentuan Umum dan Tatacara Perpajakan (KUP), tentang Pajak Penghasilan (PPH), dan tentang PPN dan $P P n B M$. Juga undang-undang tentang 
penagihan pajak dengan surat paksa, serta UU perubahan Bea perolehan hak Atas tanah dan Bangunan. Namun bukan berarti dengan upaya-upaya tersebut undangundang dan peraturan-peraturan itu tidak luput dari kekurangan dan kelemahan, seperti yang dapat dilihat dalam bagian lain tulisan ini.

\section{Process accountabiliy}

Akuntabilitas proses lebih menekankan pada bagaimana administrasi pajak dapat dilaksanakan dengan baik, sehingga pembayar pajak sebagai pihak yang telah dibebani dengan pembayaran pajak tidak lagi terbebani dengan administrasi pajak yang rumit. Dalam kaitan inj masih banyak kekurangan-kekurangan yang terdapat pada lingkungan Ditjend pajak, yaitu seperti yang dikatakan oleh Sadhani (2001) bahwa yang paling penting namun juga paling berat untuk dilakukan adalah mereformasi budaya kerja secara menyeluruh.

Masih banyak perilaku oknum fiskus yang tidak terpuji dalam mengemban amanat sebagai abdi negara dan abdi masyarakat, yang akan berdampak negatif terhadap UU yang telah dibuat sebagai langkah reformasi dalam bidang perpajakan, seperti dikatakan oleh Hidayat (2001), yaitu a) perilaku amoral yang dilakukan oleh fiskus berkait dengan pekerjaannya, seperti melakukan kongkalikong dengan WP yang bertujuan memperoleh kelebihan dari "Mengakali" beban pajak Wajib Pajak (WP). b) Arogan fiskus yang memperlihatkan kekuasaannya dalam melayani WP, tidak sesuai dengan institusi tempat fiskus yang dinamai KPP (Kantor Pelayanan Pajak). c) Birokrasi yang rumit harus disederhanakan, sehingga tidak membuat WP "alergi" untuk berurusan dengan fiskus, jangan mempertahankan prinsip "kalau bisa dipersulit mengapa harus dipermudah", tetapi harus membalikkan logika dengan "kalau bisa dipermudah mengapa harus dipersulit".

\section{Outcome accountability}

Outcome accountability adalah akuntabilitas yang berkaitan dengan bagaimana pemanfaatan perolahan pajak itu betul-betul dapat bermanfaat pada masyarakat luas, meningkatkan kesejahteraan mereka, memacu pertumbuhan ekonomi, sesuai dengan fungsi pajak, yaitu fungsi regulerend (mengatur) maupun fungsi financial (ekonomi).

\section{Dampak Kurang Meningkatnya Akuntabilitas Bidang Pajak dan Retribusi}

Kurangnya akuntabilitas pemerintah terhadap pajak dan retribusi ini sangat merugikan pemerintah sendiri, yaitu berupa 1) ketidakpercayaan masyarakat terhadap permintah dalam berbagai aspek, yaitu pada aspek hukum, keadilan, administratif maupun pada penggunaan hasil peroleh pajak. 2) Pemerintah akan kesulitan mengajak masyarakat untuk sadar dan dengan senang hati membayar pajak. 3) Masyarakat akan cenderung untuk menghindari pajak, sehingga pajak yang diharapkan menjadi tulang punggung penerimaan negara, tidak dapat dengan mudah tercapai. 4) Rendahnya kesadaran masyarakat ini menyebabkan rendahnya rasio penerimaan pajak terhadap PDB (Produk Domestik Bruto) juga rendah, yaitu untuk tahun 2001 hanya mencapai 10-11\%.

Peningkatan akuntabilitas bidang pajak diharapkan mampu meningkatkan penerimaan pemerintah yang berasal dari pajak, mengingat bahwa masih banyak tedapat ruangan untuk meningkatkan penerimaan 
negara. Ikhsan (2001) memberikan bebarapa indikator yang menunjukkan bahwa potensi penerimaan pajak masih sangat tinggi, yaitu:

1. Jika dilihat rasio penerimaan pajak terhadap PDB, penerimaan pajak di Indonesia masih relatif rendah dibandingkan dengan negara lain.

2. Angka Filing ratio yaitu rasio antara wajib pajak yang aktual membayar pajak dan wajib pajak yang tercatat (registered tax payer) belum memadai untuk ketiga pajak utama, yaitu pajak penghasilan individu, pajak penghasilan perusahaan dan pajak pertambahan nilai.

3. Realisasi penerimaan pajak untuk kesemua jenis pajak masih di bawah potensinya.

4. Elastisitas penerimaan pajak untuk semua jenis pajak masih lebih besar dari satu. Basis pengukuran elastisitas pajak adalah PDB. Hal ini menunjukkan bahwa sebetulnya potensi pajak ini masih banyak yang belum tergarap.

Dengan Akuntabilitas yang tinggi, potensi penerimaan pemerintah dari sektor pajak yang masih luas akan dapat diintensifkan.

\section{Upaya Meningkatkan Akuntabilitas Bidang Pajak dan Retribusi}

Upaya-upaya untuk meningkatkan akuntabilitas di bidang pajak dan retribusi antara lain yaitu:

1. Transparansi pada hasil perolehan pajak, yaitu dapat dilakukan antara lain dengan transparansi pelaksanaan anggaran negara: Menurut Sujanto (2001) transparansi tersebut dapat dilakukan dengan menerapkan buift-in control dalam suatu mekanisme sistem pelaksanaan anggaran untuk menghindari pemborosan dan kebocoran anggaran negara. Built-in control sistem tersebut dimanifestasikan dalam mekanisme check and balance dalam hubungan antara para pejabat pemegang kewenangan anggaran. Pemisahan kewenangan dalam pelaksanaan anggaran yang melahirkan hak dan kewajiban atau tanggung jawab bagi masing-masing pihak merupakan suatu mekanisme hubungan kerja yang mampu menunjukkan tingkat akuntabilitas masing-masing pihak, karena tidak terjadi pencampuran (overlapping) kewenangan.

2. Mengingat pajak merupakan beban rakyat, maka perangkat peraturannya harus bermutu, sederhana dan mudah dipahami, sehingga perlu penyederhanaan UU perpajakan yang telah begitu banyak mengalami perubahanperubahan itu. Prinsip-prinsip perpajakan yang baik yaitu neutrality, equity, simplicity, symmetry dan inclusiveness harus digunakan.

3. Mengingat rendahnya tax ratio (penerimaan pajak dari $\mathrm{PDB}$ ) Indonesia saat ini, tidak akan cukup untuk membayar utang dan menjalankan roda pemerintahan dalam jangka panjang, maka perlu membangun basis pajak baru, yaitu dengan menciptakan kondisi yang mampu menarik para pelaku bisnis melakukan kegiatan perdagangan dan investasi di Indonesia. Dalam hal ini tarif pajak untuk investasi harus sebanding dengan pajak yang diterapkan di negara-negara lain.

4. Perlu adanya reformasi pada administrasi pajak guna meningkatkan pelayanan di bidang pajak. Elemenelemen penting yang dibutuhkan agar 
Tuntutan Akuntabilitas Masyarakat terhadap Pemerintah atas Pajak dan...; Surifah

suatu reformasi administrasi pajak berhasil meliputi: komitmen politik yang eksplisit dan berkesinambungan, suatu tim petugas pajak yang kompeten yang dilibatkan dalam reformasi administrasi pajak, strategi reformasi yang jelas dan tepat, pelatihan yang tepat bagi staf, sumber daya tambahan untuk administrasi pajak atau paling sedikit beberapa realokasi sumberdaya, pelayanan yang berorientasi pada kepuasan pelanggan (wajib pajak) dan perubahan-perubahan dalam insentif baik untuk membayar pajak maupun bagi administrator pajak.

5. Menerapkan law enforcement pada aparat. Dalam upaya meningkatkan penerimaan pajak, selain melakukan law enforcement terhadap wajib pajak, juga yang tidak kalah pentingnya adalah melakukan law enforcement ke dalam jajaran Ditjend pajak sendiri, yakni menindak aparat pajak yang melakukan pelanggaran disiplin pegawai.

\section{Penutup}

Tuntutan akuntabilitas masyarakat terhadap pemerintah tidak hanya pada sektor keuangan saja, tetapi meliputi fiscal accountability, legal accountability, legal accountability, program accountability, process accountability dan outcome accountability. Berbagai kritik ditujukan terhadap bagaimana akuntabilitas Pemerintah sebagai pengemban amanah untuk memungut pajak dan memanfaatkan atau menggunakan hasil perolehan pajak ini sebesar-besarnya untuk keperluan dan kesejahteraan rakyat. Berbagai upaya telah dilakukan pemerintah untuk meningkatkan akuntabilitas ini, namun di sana-sini juga masih terdapat banyak kekurangan. Upaya untuk meningkatkan akuntabilitas memerlukan kerja keras dan tanggung jawab penuh yang mengarah pada efisiensi dan efektivitas. Akuntabilitas yang dituntut oleh masyarakat merupakan sesuatu yang harus dilakukan oleh pemerintah dan merupakan hak yang harus diterima oleh masyarakat.

\section{Daftar Pustaka}

Berita Pajak. 2001. berbagai sumber dari berita pajak.

Hidayat, Nur.2001. Harapan Dunia Usaha: Perubahan Undang-undang Pajak tahun 2000, Berita Pajak No. 1453, tahun XXXIV/15 Oktober 2001, hal.3435.

Ikhsan, Mohammad. 2001. Beberapa Issue dalam APBN khususnya perpajakan, Berita pajak No. 1455, tahun XXXIVI 15 Nopember 2001, hal.40-43.

Sadhani, Djazoeli.2001. Yang Terberat Adalah Mereformasi Budaya Kerja, Berita Pajak No. 1435, tahun XXXIV/ 15 Januari 2001, hal.7-8.

Subroto.2001. UU Perpajakan Yang Makin Tidak Sederhana, Berita Pajak No. 1436, tahun XXXIII/1 Februari 2001. hal.25-27.

Sujanto, Siswo.2001. Aspek Transparansi Pelaksanaan Anggaran Negara, (Tinjauan Yuridico-administratif terhadap RUU Perbendaharaan Negara, Berita Pajak No. 1436, tahun XXXIII/1 Oktober 2001, hal.25-27.

Utomo, Warsito. 2000. Tuntutan Akuntabilitas Masyarakat Dalam Pelaksanaan Otonomi Daerah, Makalah 